\title{
Application of Ziziphus Jujube (Red Date), Camellia Sinensis (Black Tea) and Aleurites Moluccana (Candle Nut) Marinades as Beef Meat Tenderizer
}

\author{
Mohamad Afifi Ismail ${ }^{1}$, Mohamad Anuar Ibrahim ${ }^{1}$, Mohamad Rashedi Ismail-Fitry ${ }^{1 *}$ \\ ${ }^{1}$ Department of Food Technology, Faculty of Food Science and Technology, Universiti Putra Malaysia 43400 UPM Serdang, Selangor, \\ Malaysia \\ *Corresponding author E-mail: ismailfitry@upm.edu.my
}

\begin{abstract}
This study was carried out to analyse Ziziphus jujube (red date), Camellia sinensis (black tea) and Aleurites moluccana (candlenut) extract as the potential beef tenderizer. The beef meat chunks $\left(3 \mathrm{~cm}^{3}\right)$ were marinated with the extracts at different concentrations $(20 \%$, $40 \%$ and $60 \%$ ) for 24 hours at $4^{\circ} \mathrm{C}$. Both raw and cooked samples were subjected to physicochemical analyses and sensory evaluation. Overall, there were slight changes in $\mathrm{pH}$ values and increased in moisture content for all the treated samples. The increased concentration of extracts resulted in decreased cooking loss and the hardness from texture profile analysis (TPA) of the treated sample compared to the control. The colour analysis showed a significant $(\mathrm{p}<0.05)$ different in term of lightness, redness and yellowness of all treated meat chunks. Increased concentration of extracts reduced the redness of meat samples. The sensory evaluation indicated that the tenderness, juiciness and overall acceptability of all treated samples were significantly $(\mathrm{p}<0.05)$ higher compared to control. It can be suggested that the marination of meat with Ziziphus jujube (red date), Camellia sinensis (black tea) and Aleurites moluccana (candlenut) extracts have the ability to tenderize the meat as the toughness decreased in all treated samples with Ziziphus jujube (red date) was the best tenderizer.
\end{abstract}

Keywords: Ziziphus jujube, Camellia sinensis, Aleurites moluccana, marinades, meat tenderizers

\section{Introduction}

The beef consumption around the world is almost $25 \%$ of meat production worldwide [1]. It is in the third place of most widely consumed meat in the world after pork and poultry. One of the quality attributes that affect the consumer perception towards meat is tenderness [2]. Tenderness defined as the resistance of meats to be cut. The meat toughness is associated with the muscle connective tissue of animal especially the older animal [3].

The previous study found that the postmortem process is effective to reduce meat toughness. Postmortem processes such as physical, chemical and enzymatic treatment are widely used in the meat industry [4]. One of the common post-mortem technique to tenderize meat is marination, which had been practiced for a long period of time. Marination basically involves the infusion, injection and tumbling of meat with marinades. The marination techniques effectively improved the tenderness, juiciness, flavour and colour of meat.

The common proteolytic enzyme derived from the plant such as tannins from black tea, papain from papaya, and bromelain from pineapple. The presence of plant protease possesses the ability to break down protein naturally [5]. There are also other potential of plant extracts recently studied to tenderize meat such as Averrhoa bilimbi (belimbing buluh), Actinidia chinensis (kiwifruit), and Citrus limon (lemon) [6].

Camellia sinensis, commonly known as black tea is the most popular beverages in the world [7]. The beverages from tea products considered the highest to provide antioxidants which related to the higher content of polyphenols [8]. Other than that, black tea is also has potential to tenderize meat during cooking [9]. Aleurites moluccana which is also known as candlenut, is widespread throughout the tropical region especially Malaysia and Indonesia [10]. Several parts of this plant are used for traditional medicines. Apart from that, candle nut is commonly used in some tropical cuisine due to its function as a flavour enhancer. Candlenut may also have the potential to be used as a meat tenderizer [11]. Ziziphus jujube mill (Chinese date or red date) was a native fruit of China and has been cultivated for more than 2500 years [12]. They are grown in the subtropical and temperate area especially in the Northern Hemisphere like North China [13]. Red dates are used mainly in Chinese culture, especially in food as the food additive and flavouring.

Red dates, black tea and candlenut have been claimed and used traditionally to tenderize meat. However, there is a lack of scientific literature to these practices. Thus, this study aimed to determine the effects of red dates, black tea and candlenut extract treatments on tenderizing the beef meats.

\section{Materials and Methods}

\subsection{Sample Preparation}

Fresh beef brisket meat was obtained from Selangor Wholesale Market and stored at $-20^{\circ} \mathrm{C}$ until sample preparation. After 24 hours of thawing at $4{ }^{\circ} \mathrm{C}$, the meats were cut into the $3 \mathrm{~cm}^{3}$ size and randomly allotted for different treatments according to the experimental design. 


\subsection{Fruit extracts preparation}

Dried red dates (RD), black tea (BT) and candlenut (CN) were purchased from Selangor wholesale market (Selangor, Malaysia). All the raw materials were cleaned with tap water to remove unwanted materials. Then, the samples were grounded separately to a powder form before extraction. The sample powders were extracted by using hot water extraction for 30 minutes at $60^{\circ} \mathrm{C}$ with ratio 1:1 as described by Ionescu, Aprodu \& Pascaru [14]

\subsection{Plant extract treatment and marination}

About $3 \mathrm{~cm}^{3}$ uniform size of beef meat chunks were marinated with different concentrations ( $0 \%$ as control, $20 \%, 40 \%$, and $60 \%$ $\mathrm{v} / \mathrm{v}$ ) of red date, black tea or candlenut extracts, respectively. The $20 \%$ percent concentration of extract solution was prepared by $20 \mathrm{ml}$ of extract solution added with a volume of distilled water to make it $100 \mathrm{ml}$. The meat samples were marinated with extract solution at ratio 1:2 (1 is the weight of meat, 2 is the volume of extract). After thorough mixing manually, the chunks were placed in polyethylene bags and kept at $4 \pm 1^{\circ} \mathrm{C}$ for 24 hours. After 24 hours of marinating, the meat pieces were drained and cooked in the oven for 20 minutes at $75^{\circ} \mathrm{C}$ based on the method by [5] with some modifications. The cooked samples were evaluated for $\mathrm{pH}$, cooking yield, expressible water, colour, texture profile analysis and sensory evaluation.

\section{4. pH, moisture and cooking loss determination}

For $\mathrm{pH}$ determination, $10 \mathrm{~g}$ of the treated sample was homogenized with $50 \mathrm{ml}$ of chilled distilled water and the $\mathrm{pH}$ values were measured using a digital $\mathrm{pH}$ meter (Jenway, Staffordshire, UK) The moisture content of the cooked meats was measured by using an automatic moisture analyzer (Sortorius MA35, UK) based on the method by Yilmaz [15]. The meat sample (1-3g) was used for the analysis of the temperature of the moisture analyzer set at $105^{\circ} \mathrm{C}$. The percent of cooking loss was calculated as the difference in weight between individual raw and cooked meat samples.

\subsection{Texture profile analysis (TPA)}

The textural properties of the meat chunks were evaluated using TPA. Texture Profile Analyzers (Stable Micro system Ltd., TA$\mathrm{Xt} 2 \mathrm{i}, \mathrm{UK})$, fitted with a blade set with a $5 \mathrm{~kg}$ load cell and cylindrical probe (diameter, $75 \mathrm{~mm}$ ). A compression speed of 5.00 $\mathrm{mm} \mathrm{s}^{-1}$ with $2.00 \mathrm{~mm} \mathrm{~s}^{-1}$ of pre-test speed and $5.00 \mathrm{~mm} \mathrm{~s}^{-1}$ of posttest speed was applied to the cubes. Hardness, springiness, cohesiveness, and chewiness were calculated from the forces deformation curves. TPA parameters were measured according to method outlined by Naveena, Mendiratta \& Anjaneluyu [5].

\subsection{Colour analysis}

The colour analysis of the meat samples was carried out according to the method described by Du et al. [16]. The colour of the meat chunks was measured using a Mini Scan XE Plus colourimeter (Hunter Associates Laboratory Inc., USA). The L* (lightness), a* (redness) and $\mathrm{b}^{*}$ (yellowness) values were obtained using EasyMatch QC Data System software. The average score of triplicate experiments was recorded and expressed as CIE lightness $\left(\mathrm{L}^{*}\right)$, redness $\left(\mathrm{a}^{*}\right)$, and yellowness $\left(\mathrm{b}^{*}\right)$.

\subsection{Sensory evaluation}

All cooked meat chunks were evaluated using the 7-point hedonic scales $(1=$ Dislike very much, $4=$ Neither like or dislike, $7=$ Like very much) for sensory characteristics (i.e. colour, flavour, tenderness, juiciness and overall acceptability) by 30 untrained panellist according to guidelines of American Meat Science Association (1995).

\subsection{Statistical analysis}

All data were analyzed by one-way ANOVA using Minitab version 17 (Minitab, Statistical Software, USA). Tukey's test was used to determine the significant differences among means for different treatments. The accepted level of significance for all comparison was $(\mathrm{p}<0.05)$.

\section{Results and Discussion}

\subsection{Moisture Content}

The moisture content of meats with different concentration of natural plant extract ranged from $51.53 \%$ to $52.80 \%$ as shown in Table 1. Overall, the moisture content of meat treated with RD40\%, RD60\%, BT60\%, and CN60\% was significantly higher $(\mathrm{p}<0.05)$ compared to the control. Meanwhile, no significant differences ( $p>0.05)$ were observed among Control, CN20\%, $\mathrm{CN} 40 \%$. BT20\%, BT40\% and RD20\%. The lowest moisture content $(51.53 \% \pm 0.34)$ was recorded in meat samples treated with RD20\%. From the results, it can be seen that the moisture content of meat was increased $(\mathrm{p}<0.05)$ as the plant extract ratio incorporated increased. Similar findings also reported by Naveena, Mendiratta \& Anjaneluyu [5] who found that increase in moisture content of buffalo meat with increasing concentration of Ginger extract. The increased moisture content of treated meat might be due to the improvement of hydrophilic characteristics of meats. Besides, the ability of meat to bind with a high amount of water had influenced the increase in moisture content of treated meat [17]. Higher moisture content is very important to indicate less water was expressed from meat and this behaviour had contributed to the juiciness of meat products [18]. The muscle approximately contains $75 \%$ of water (moisture), $20 \%$ protein and another 5\% are a combination of fat, carbohydrate and mineral [19]. Hence, the water holding capacity had a great contribution to the juiciness of the meat.

Table 1: Physicochemical properties of meat treated with Red Date, Black Tea and Candle Nut

\begin{tabular}{ccllc}
\hline Sample & $\begin{array}{l}\text { Concentration } \\
(\%)\end{array}$ & $\begin{array}{l}\text { Moisture } \\
(\%)\end{array}$ & $\mathrm{pH}$ & $\begin{array}{l}\text { Cooking } \\
\text { Loss }(\%)\end{array}$ \\
\hline $\mathrm{C}$ & 0 & $51.73 \pm 0.03^{\mathrm{bc}}$ & $5.76 \pm 0.06^{\mathrm{a}}$ & $51.61 \pm 4.02^{\mathrm{a}}$ \\
$\mathrm{RD}$ & 20 & $51.53 \pm 0.34^{\mathrm{c}}$ & $5.60 \pm 0.02^{\mathrm{c}}$ & $48.45 \pm 4.13^{\mathrm{ab}}$ \\
& 40 & $52.63 \pm 0.07^{\mathrm{a}}$ & $5.57 \pm 0.02^{\mathrm{c}}$ & $50.94 \pm 1.81^{\mathrm{a}}$ \\
& 60 & $52.80 \pm 0.04^{\mathrm{a}}$ & $5.68 \pm 0.06^{\mathrm{b}}$ & $48.26 \pm 4.35^{\mathrm{ab}}$ \\
$\mathrm{BT}$ & 20 & $51.99 \pm 0.06^{\mathrm{b}}$ & $5.73 \pm 0.03^{\mathrm{ab}}$ & $49.85 \pm 2.83^{\mathrm{ab}}$ \\
& 40 & $51.69 \pm 0.04^{\mathrm{bc}}$ & $5.73 \pm 0.04^{\mathrm{ab}}$ & $45.46 \pm 2.69^{\mathrm{b}}$ \\
$\mathrm{CN}$ & 60 & $52.41 \pm 0.47^{\mathrm{a}}$ & $5.69 \pm 0.06^{\mathrm{ab}}$ & $48.61 \pm 4.18^{\mathrm{ab}}$ \\
& 20 & $51.57 \pm 0.46^{\mathrm{c}}$ & $5.74 \pm 0.04^{\mathrm{ab}}$ & $50.46 \pm 2.89^{\mathrm{a}}$ \\
& 40 & $51.57 \pm 0.46^{\mathrm{c}}$ & $5.73 \pm 0.06^{\mathrm{ab}}$ & $51.82 \pm 3.42^{\mathrm{a}}$ \\
& 60 & $52.71 \pm 0.07^{\mathrm{a}}$ & $5.71 \pm 0.04^{\mathrm{ab}}$ & $48.71 \pm 2.78^{\mathrm{ab}}$ \\
\hline
\end{tabular}

C; Control, RD; Red Date, BT; Black Tea and CN; Candle Nut

Mean with the different letter in the same column are significantly different $(\mathrm{p}<0.05)$

\section{2. $\mathrm{pH}$ value}

The $\mathrm{pH}$ values of different meat samples ranged from $5.57 \pm 0.02$ to $5.76 \pm 0.06$ as shown in Table 1. Experimental data showed a significant $(\mathrm{p}<0.05)$ reduction in the $\mathrm{pH}$ of meat samples treated with RD for all the concentrations compared to the control. However, there was no significant difference $(p>0.05)$ for other treatments as compared to the control samples. All treated meat samples only showed a slight $(\mathrm{p}>0.05)$ reduction in $\mathrm{pH}$ compared with control. The result also indicates that the $\mathrm{pH}$ of treated meat decreased as the concentration of plant extract increased.

The change in $\mathrm{pH}$ of meat was influenced by the type of marinade apply either acidic or alkaline. Thus, the nature of plant extract 
affects the $\mathrm{pH}$ of meat. In this study, the $\mathrm{pH}$ of the Red Date, Black Tea and Candle Nut were 5.49, 5.20 and 6.50 respectively. The treatment of various plant extracts had altered the $\mathrm{pH}$ of meat chunks. The decreased of $\mathrm{pH}$ of treated samples compared to the control might be due to percentages of the concentrations that allow changes in the meat $\mathrm{pH}$ as marinade solution and exogenous acid also react where they slowly penetrate and attack the muscle on the targeted protein. The normal $\mathrm{pH}$ of beef was $5.6 \pm 0.04$ as reported by the previous study [20].

\subsection{Cooking Loss}

Table 1 shows the meat sample treated with BT40\% resulted in significant $(\mathrm{p}<0.05)$ reduction in cooking loss $(45.46 \pm 2.69 \%)$ compared to the control. Only slight $(\mathrm{p}>0.05)$ decrease in cooking loss of meat samples treated with RD20\%, RD60\%, BT20\%, BT60\%, CN20\%, and CN60\% compared to control were recorded. However, no significant different $(p>0.05)$ was observed between Control, RD40\% and $\mathrm{CN} 40 \%$. There were also no significant different recorded within the RD20\%, RD60\%, BT20\%, BT60\%, $\mathrm{CN} 20 \%$, and $\mathrm{CN} 60 \%$ treated samples. BT $40 \%$ exhibit less cooking loss compared to other samples and this indicates that BT $40 \%$ treatment could reduce the cooking loss of the sample. The tenderization of meat might be due to the preferential interaction of catechins with connective tissues.

The previous study conducted by Gerelt, Ikeuchi and Suzuki [21] also reported the reduction of cooking loss of meat treated with a solution containing proteolytic enzymes. The absorption of enzyme solution ratio almost linearly increased with the increased of enzymes extract percentages and longest dipping time [21]. In other study showed that the heat treatment has influenced the result of the cooking loss. The internal temperature of meat during cooking also related to high results of cooking loss where the myofibrillar protein denaturation caused structural changes [22]. The increase of internal temperature of meat during cooking will increase the cooking loss. When the muscle is subjected to heating, coagulation of proteins and thermal shrinkage of meat take places resulting in the release of meat juices. Cooking losses are dependent on the type of meat, time, temperature and method of cooking [19].

\subsection{Texture Profile Analysis (TPA)}

Textural properties of the meat are the important factors that favour consumers towards meat products. Table 2 shows the treatment of different plant extracts and concentration altered the textural properties of meat chunks in terms of hardness, springiness, cohesiveness and chewiness.

The hardness of treated meat decreased gradually as the concentration of plant extracts increased. The hardness of meat treated with RD60\% and BT60\% were significantly $(\mathrm{p}<0.05)$ reduced compared to the control. The parameter of hardness is the most important since the lower the hardness value, the softer the meats. The reduction of hardness in all treated samples are similar with the previous study conducted by Burke \& Monahan [23] in which hardness of meat samples was highly decreased with high percentages of marinating solution extracts and longer marinating period. The improved of tenderness also related to the temperature while marinating where cooler conditioning of meat at $4^{\circ} \mathrm{C}$ enhance degradation of muscle protein by proteolytic enzymes [24].

Table 1: Textural properties of meat samples treated with Red Date, Black Tea and Candle Nut

\begin{tabular}{lccccc}
\hline $\begin{array}{l}\text { Sampl } \\
\mathrm{e}\end{array}$ & $\begin{array}{c}\text { Concentrati } \\
\text { on }(\%)\end{array}$ & $\begin{array}{l}\text { Hardne } \\
\text { ss (N) }\end{array}$ & $\begin{array}{l}\text { Springine } \\
\text { ss }\end{array}$ & $\begin{array}{l}\text { Cohesivene } \\
\text { ss }\end{array}$ & $\begin{array}{l}\text { Chewine } \\
\text { ss (N) }\end{array}$ \\
\hline \multirow{2}{*}{$\mathrm{C}$} & 0 & $\begin{array}{c}165.6 \pm \\
64.70^{\mathrm{a}}\end{array}$ & $\begin{array}{c}0.94 \pm \\
0.02^{\mathrm{a}}\end{array}$ & $\begin{array}{c}0.73 \pm \\
0.06^{\mathrm{a}}\end{array}$ & $\begin{array}{c}108.56 \pm \\
4.07^{\mathrm{b}}\end{array}$ \\
\hline \multirow{2}{*}{$\mathrm{RD}$} & 20 & 108.69 & $0.87 \pm$ & $0.84 \pm$ & $74.46 \pm$ \\
& & $\begin{array}{c} \pm \\
\mathbf{a n}^{\mathrm{ab}}\end{array}$ & $0.88^{\mathrm{a}}$ & $0.04^{\mathrm{a}}$ & $2.56^{\mathrm{de}}$
\end{tabular}

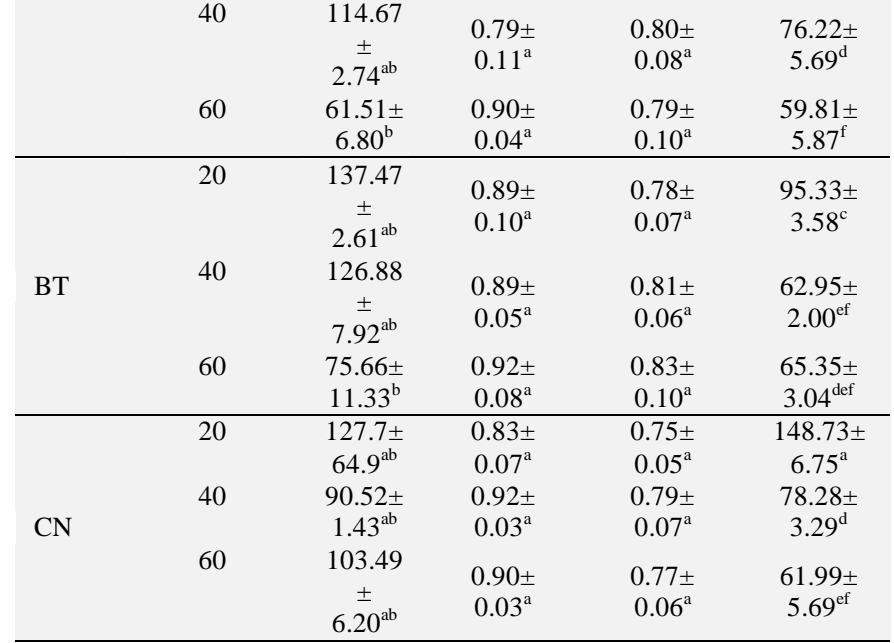

C; Control, RD; Red Date, BT; Black Tea and CN; Candle Nut

Mean with the different letter in the same column are significantly different $(\mathrm{p}<0.05)$

Meanwhile, there were no ( $p>0.05)$ significant differences for parameters of springiness and cohesiveness for all treated samples in comparison with the control. All treatments resulted in significant $(\mathrm{p}<0.05)$ reduction in chewiness in comparison with control. RD60\% meat samples had lower chewiness values $(59.81 \pm 5.87 \mathrm{~N})$ among the other meats samples. The decreased value of chewiness indicates the evidence of marinade solution diffused through the meat muscle to reduce the meat hardness [21].

\subsection{Colour}

Table 3 shows the colour analysis of the treated meat samples. There were significant differences $(\mathrm{p}<0.05)$ recorded for the lightness $(L)$ of all treated meats samples as compared to the control. Lightness value $(L)$ was decreased significantly $(\mathrm{p}<0.05)$ with increasing concentration of plant extracts. This finding in line with the study by Cho et al. [25], in which increased marinating concentration will result in darker fillet colour compared to unmarinated meats.

Redness (a) value of treated samples was decreased significantly $(\mathrm{p}<0.05)$ when compared to control except for $\mathrm{BT} 40 \%$ and $\mathrm{CN} 20 \%$. Redness $(a)$ of meat samples decreased gradually as the concentration of extracts was increased except for candlenut extracts. Overall, Candlenut treated samples recorded lowest redness $(a)$ followed by Red Dates and Black Tea treated samples. Redness $(a)$ of meat was significantly decreased when treated with black tea extract because of the darker colour of black tea extracts. Previous researchers reported that the colour development of cooked meats could also be affected by cooking methods [26].

Table 2: Colour analysis of meat samples treated with Red Date, Black Tea and Candle Nut

\begin{tabular}{clccc}
\hline $\begin{array}{l}\text { Sampl } \\
\text { e }\end{array}$ & $\begin{array}{l}\text { Conce } \\
\text { ntrati } \\
\text { on } \\
(\%)\end{array}$ & Lightness $(L)$ & Redness $(a)$ & $\begin{array}{c}\text { Yellowness } \\
(b)\end{array}$ \\
\hline C & 0 & $54.20 \pm 0.53^{\mathrm{a}}$ & $4.08 \pm 0.09^{\mathrm{a}}$ & $8.76 \pm 0.21^{\mathrm{de}}$ \\
$\mathrm{RD}$ & 20 & $50.99 \pm 0.55^{\mathrm{b}}$ & $3.32 \pm 0.04^{\mathrm{d}}$ & $8.68 \pm 0.06^{\mathrm{de}}$ \\
& 40 & $50.55 \pm 0.07^{\mathrm{bc}}$ & $3.87 \pm 0.02^{\mathrm{b}}$ & $9.12 \pm 0.29^{\mathrm{bc}}$ \\
& 60 & $48.47 \pm 0.22^{\mathrm{d}}$ & $3.82 \pm 0.09^{\mathrm{b}}$ & $8.79 \pm 0.07^{\mathrm{d}}$ \\
$\mathrm{BT}$ & 20 & $46.96 \pm 0.71^{\mathrm{g}}$ & $3.22 \pm 0.05^{\mathrm{de}}$ & $8.83 \pm 0.02^{\text {ed }}$ \\
& 40 & $47.79 \pm 0.27^{\text {ef }}$ & $4.09 \pm 0.11^{\mathrm{a}}$ & $8.45 \pm 0.03^{\mathrm{e}}$ \\
& 60 & $47.87 \pm 0.06^{\mathrm{de}}$ & $3.84 \pm 0.07^{\mathrm{b}}$ & $8.67 \pm 0.31^{\mathrm{de}}$ \\
$\mathrm{CN}$ & 20 & $50.25 \pm 0.41^{\mathrm{c}}$ & $4.08 \pm 0.08^{\mathrm{a}}$ & $9.35 \pm 0.17^{\mathrm{b}}$ \\
& 40 & $47.41 \pm 0.55^{\text {efg }}$ & $3.69 \pm 0.08^{\mathrm{e}}$ & $8.70 \pm 0.03^{\mathrm{de}}$ \\
& 60 & $47.14 \pm 0.46^{\mathrm{fg}}$ & $3.19 \pm 0.08^{\mathrm{e}}$ & $9.98 \pm 0.04^{\mathrm{a}}$ \\
\hline
\end{tabular}

C; Control, RD; Red Date, BT; Black Tea and CN; Candle Nut Mean with the different letter in the same column are significantly different $(\mathrm{p}<0.05)$ 
Yellowness (b) did not vary among the Control, RD40\%, BT20\%, BT60\%, RD60\% and B40\%. The highest yellowness $(9.98 \pm 0.04)$ was recorded in the sample treated with $\mathrm{CN} 60 \%$. As the proportion of extract percentages increase, the yellowness also increased except for black teas that have inconsistent $b$-value. The yellowness values of different samples of meat were increased and this result was in line with the study conducted by Narsaiah et al. [27] in which the marinade solution accumulate on the surface of the meat while marinating will increase yellowness value of the samples.

\subsection{Sensory}

Based on the hardness results from the textural profile analysis (TPA), the best three results were all came from $60 \%$ of the extract marinated samples which were RD60\%, BT60\% and CN60\%. Tenderness, juiciness, aroma and overall palatability were the sensory attributes that have been evaluated by 30 untrained panellists and presented in Table 4. The 7-point hedonic scale had been used for this sensory analysis.

Table 3: Sensory properties of meat sample treated with Red Date, Black tea and Candle Nut

\begin{tabular}{ccccc}
\hline Sampl & Tenderness & Juiciness & Aroma & $\begin{array}{l}\text { Overall } \\
\text { Acceptability }\end{array}$ \\
\hline C & $2.87 \pm 1.432^{\mathrm{b}}$ & $3.53 \pm 1.592^{\mathrm{b}}$ & $3.33 \pm 1.446^{\mathrm{b}}$ & $3.17 \pm 1.510^{\mathrm{b}}$ \\
RD60 & $4.03 \pm 1.752^{\mathrm{ab}}$ & $4.40 \pm 2.010^{\mathrm{ab}}$ & $3.87 \pm 1.655^{\mathrm{ab}}$ & $3.73 \pm 1.639^{\mathrm{ab}}$ \\
BT60 & $4.40 \pm 1.886^{\mathrm{a}}$ & $5.13 \pm 1.907^{\mathrm{a}}$ & $4.47 \pm 1.730^{\mathrm{a}}$ & $4.78 \pm 1.591^{\mathrm{a}}$ \\
CN60 & $4.10 \pm 1.936^{\mathrm{a}}$ & $4.70 \pm 1.664^{\mathrm{ab}}$ & $4.20 \pm 1.756^{\mathrm{ab}}$ & $4.30 \pm 1.557^{\mathrm{a}}$ \\
\hline
\end{tabular}

C; Control, RD60; Red Date 60\% concentration, BT60; Black Tea 60\% concentration and CN60; Candle Nut $60 \%$ concentration

Mean with the different letter in the same column are significantly different $(\mathrm{p}<0.05)$

The red date, black tea and candlenut extract marination resulted in increased $(p<0.05)$ score in tenderness, juiciness, aroma and overall acceptability. There were significantly higher scores $(p<0.05)$ for tenderness attributes of all treated samples compared to the control. However, there were no significant differences (p>0.05) recorded between BT60\%, RD60\% and CN60\% meats samples. The used of plant protease for example pomegranate to tenderize goat meat also resulted in improved tenderness [27]. The juiciness of meat samples treated with RD60\% recorded the highest scores compared to others. There were slight differences in juiciness between meat samples treated with BT60\% and CN60\%. The higher juiciness of meat samples might be attributed to the higher moisture content of samples treated with plant extracts. Improved tenderness and juiciness of meats were highly associated with the degradation of connection between the myofibrils and collagen as described by Koohmaraie [28]. BT60\% recorded highest score for aroma compare to others. CN60\% and RD60\% recorded slightly higher $(p>0.05)$ scores for aroma compared to the control. The overall acceptability of meat samples treated with $\mathrm{BT} 60 \%$ and $\mathrm{CN} 60 \%$ were higher compared to control.

\section{Conclusion}

The result from this study shows that there were improvement in the physicochemical and sensory properties of meat marinated with natural plant extracts such as red date (Ziziphus jujube), black tea (Camellia Sinensis) and candlenut (Aleurites Moluccana). The hardness of meat samples were significantly reduced when treated with these plant extracts. The marination resulted in lower $\mathrm{pH}$ value, higher moisture content, lower cooking loss and better texture. Besides that, a higher score for sensory attributes of all treated samples indicated that marination technique is useful to tenderize meat. Overall, RD60\% was selected to be the best beef tenderizer for this project based on the TPA analysis and the rating by the panellist. This study showed that red dates have a greater potential as meat tenderizer compared to black tea and candlenut. In conclusion, marination of meat samples with natural plant extract could give noticeable effect to the structural muscle protein of the meat that make the meat tender.

\section{Acknowledgement}

The authors would like to thank Universiti Putra Malaysia for the financial support.

\section{References}

[1] Ballin, NZ (2010). Authentication of meat and meat products. Meat Science 86(3), 577-587.

[2] Tornberg E (1996). Biophysical aspects of meat tenderness. Meat Science 43(1).

[3] Purslow PP (2005). Intramuscular connective tissue and its role in meat quality. Meat Science 70(3), 435-447.

[4] Huff-Lonergan E, Zhang W, \& Lonergan SM (2010). Biochemistry of postmortem muscle - Lessons on mechanisms of meat tenderization. Meat Science 86(1), 184-195.

[5] Naveena BM, Mendiratta SK, \& Anjaneyulu ASR (2004). Tenderization of buffalo meat using plant proteases from Cucumis trigonus Roxb (Kachri) and Zingiber officinale roscoe (Ginger rhizome). Meat Science, 68(3), 363-369.

[6] Ismail MA, Chong GH, \& Ismail-Fitry MR (2018). Potential Effect of Averrhoa bilimbi (belimbing buluh) Marinades on Tenderizing the Buffalo Meat Compared to Actinidia chinensis (kiwifruit), Citrus limon (lemon) and Commercial Bromelain. Journal of Science and Technology. 10(2), 77-84.

[7] Jiang H, Engelhardt UH, Thräne C, Maiwald B \& Stark J (2015). Determination of flavonol glycosides in green tea, oolong tea and black tea by UHPLC compared to HPLC. Food chemistry 183, 3035 .

[8] Liu S \& Huang H (2015). Assessments of antioxidant effect of black tea extract and its rationals by erythrocyte haemolysis assay, plasma oxidation assay and cellular antioxidant activity (CAA) assay. Journal of Functional Foods 18, 1095-1105.

[9] Shahidi F \& Alexander DM (1998). Green tea catechins as inhibitors of oxidation of meat lipids. Journal of Food Lipids 5(2), $125-133$

[10] Tarigan E, Prateepchaikul G, Yamsaengsung R, Sirichote A, \& Tekasakul P (2007). Drying characteristics of unshelled kernels of candle nuts. Journal of Food Engineering 79(3), 828-833.

[11] NA NN, Budi RS, Omar A, \& MO (2004). Major chemical constituents of candle nut oil extract using supercritical carbon dioxide. Malaysian Journal of Pharmaceutical Sciences 2(1), 6172.

[12] Li H, Li F, Wang L, Sheng J, Xin Z, Zhao L, \& Hu Q (2009). Effect of nano-packing on preservation quality of Chinese jujube (Ziziphus jujuba Mill. var. inermis (Bunge) Rehd). Food chemistry 114(2), 547-552.

[13] Zhang H, Jiang L, Ye S, Ye Y, \& Ren F (2010). Systematic evaluation of antioxidant capacities of the ethanolic extract of different tissues of jujube (Ziziphus jujuba Mill.) from China. Food Chem. Toxicology 48(6), 1461-1465.

[14] Ionescu A, Aprodu I, \& Pascaru G (1997). Effect of papain and bromelin on muscle and collagen proteins in beef meat. Ann. Univ. Dunarea Jos Galati 31, 9-16.

[15] Yilmaz I (2005). Physicochemical and sensory characteristics of low fat meatballs with added wheat bran. Journal of Food Engineering 69(3), 369-373.

[16] Du M, Nam KC, Hur SJ, Ismail H, Kim YH, \& Ahn DU (2003). Quality characteristics of irradiated chicken breast rolls from broilers fed different levels of conjugated linoleic acid. 63, 249255.

[17] Wu G, Farouk MM, Clerens S, \& Rosenvold K (2014). Effect of beef ultimate $\mathrm{pH}$ and large structural protein changes with aging on meat tenderness. Meat Science 98(4), 637-645.

[18] Savadkoohi S, Hoogenkamp H, Shamsi K, \& Farahnaky A (2014) Color, sensory and textural attributes of beef frankfurter, beef ham and meat-free sausage containing tomato pomace. Meat Science 97(4), 410-418.

[19] Lawrie RA, and Ledward DA, (2006) Lawrie's meat science, 7th edition. Cambridge, England.: Woodhead Publishing Limited.

[20] Valin C, Pinkas A, Dragnev H, Boikovski S \& Polikronov D 
(1984). Comparative study of buffalo meat and beef. Meat Science 10(1), 69-84.

[21] Gerelt B, Ikeuchi Y \& Suzuki A (2000). Meat tenderization by proteolytic enzymes after osmotic dehydration. Meat Science 56)(3), 311-318

[22] Kondjoyan A, Oillic S, Portanguen S, \& Gros JB (2013). Combined heat transfer and kinetic models to predict cooking loss during heat treatment of beef meat. Meat Science 95(2), 336-344.

[23] Burke RM \& Monahan FJ (2003). The tenderisation of shin beef using a citrus juice marinade. Meat Science 63(2), 161-168.

[24] Kemp CM, Sensky PL, Bardsley RF, Buttery PJ, \& Parr T (2010). Tenderness - An enzymatic view. Meat Science 84(2), 248-256.

[25] Cho S, Kang G, Seong PN, Park B, \& Kang SM (2015). Effect of slaughter age on the antioxidant enzyme activity, color, and oxidative stability of Korean Hanwoo (Bos taurus coreanae) cow beef. Meat Science 108, 44-49.

[26] Tian X, Wu W, Yu Q, Hou M, Jia F, Li X, \& Dai R (2016). Quality and proteome changes of beef $\mathrm{M}$. longissimus dorsi cooked using a water bath and ohmic heating process. Innovative Food Science \& Emerging Technologies 34, 259-266.

[27] Narsaiah K, Jha SN, Devatkal SK, Borah A, Singh DB, \& Sahoo J (2011). Tenderizing effect of blade tenderizer and pomegranate fruit products in goat meat. Journal of Food Science Technology 48(1), 61-68.

[28] Koohmaraie M (1996). Biochemical factors regulating the toughening and tenderization processes of meat. Meat Science 43, 193-201. 